\title{
PROFESSIONAL PRACTICE SHAPE SHIFTING. APPLYING AGILE DESIGN PRINCIPLES TO SELF-DETERMINED LEARNING
}

\author{
Ray O'Brien
}

\section{INTRODUCTION}

This article describes how a learner can apply agile design principles to create a self-determined professional practice learning experience for themselves. While previous research has emphasised the need for an agile approach to learning the iterative nature of the design phase of self-determined learning is described here from the learner's perspective.

A storyboard was used to examine a sample of narrative from my own experience developing a learning agreement for a Doctor of Professional Practice research project. The storyboard is based on common elements of agile design. The use of the storyboard exposed the agile design steps that had inadvertently been used while self-determining the learning to be undertaken. The storyboard is proposed as a tool to support learners as they determine their own learning within the context of a qualification based on heutagogical principles.

\section{REVIEW OF LITERATURE}

This brief review of literature provides an overview of the theoretical basis of both agile design and heutagogy. It then provides an insight as to synergies between agile design and heutagogy for the 2 Ist century learner. A significant gap in literature is identified.

\section{AGILE DESIGN}

Agile principles were described in the Agile Manifesto (Agile Alliance, 200I). While initially articulated to inform software design, the principles have been applied to a range of contexts including learning design (Allen \& Sites, 20 I2; Arimoto, Barbosa, \& Barroca, 20 I5; Murthi, 20 17). While the manifesto does not provide a definition of agility, it does provide values to guide the delivery of high-quality designs in an agile manner. At its core, this means rapidly and flexibly creating a response to change in design requirements at any stage in the design process (Dingsøyr, Nerur, Balijepally, \& Moe, 20I2; Henderson-Sellers \& Serour, 2005; Highsmith \& Cockburn, 200 I). This has been described as lightness, leanness, nimbleness, quickness, dexterity, suppleness or alertness (Cockburn, 2006; Erickson, Lyytinen, \& Siau, 2005). It has been related to having minimal formal processes (Ries, 2017). Conboy defines agility as the continued readiness "to rapidly or inherently create change, proactively or reactively embrace change, and learn from change while contributing to perceived customer value (economy, quality, and simplicity), through its collective components and relationships with its environment" (2009, p. 340). This approach to creating value has been seen as more iterative that the traditional linear waterfall approach design (Balaji, 20 2; Palmquist, Lapham, Miller, Chick, \& Ozkaya, 20।3). 
The stages in each iteration of design, all tend to include elements of discovering solutions to a problem, designing and producing a prototype for testing, and then making adaptations based in the test results ('A Designer's Introduction to "Agile" Methodology', 20I5; Ambler, 200 I; Dam and Siang, 2019). The most common labels for the stages in interactive processes include: input/insight, analysis, synthesis, evaluation and communication or delivery (Bagnall and Koberg, 198I; Cross, 200 I; Duberly, 2004; Kumar, 2003; Rengifo, 2018). These labels are adopted later in this article to describe the stages of an agile design process.

\section{HEUTAGOGY}

While pedagogy is used as a generic term describing the study of the processes of learning, it is more accurately the study of the processes through which children learn (Holmes and Abington-Cooper, 2000). Andragogy is a more precise term for the study of processes of learning in adults, which emphasises the self-directedness of adult learning (Merriam, 200 I). Heutagogy was introduced as a theory of self-determined learning by Kenyon and Hase (200 I). They describe heutagogy as an extension of the continuum from pedagogy, to andragogy. In heutagogy the learner is responsible not only for how and when to learn as in andragogy, but also for what to learn. In heutagogy the learner can decide on what to include in their curriculum. It has been hailed as an approach which is highly relevant to lifelong learning, professional learning and online social learning (Agonács \& Matos, 20 19; Blaschke, 20 I2; Cochrane \& Narayan, 20I3; Mann, Ker, Eden-Mann, \& O 'Brien, 2017; Mann, Ker, Eden-Mann, \& O'Brien, 20I7; Narayan, Herrington, \& Cochrane, 20 I 8). Learning within a heutagogical approach is not linear. It incorporates double loop learning which is a strong link between heutagogy and agile design principles (Blaschke, 20 I2; Hase, 20 I6).

\section{SYNERGY BETWEEN AGILE DESIGN AND HEUTAGOGY}

Nerur \& Balijepally (2007), describe how design thinking has evolved to meet the requirements of changes in context. As the environment becomes less predictable and the nature of the problem becomes increasingly wicked, the nature of the learning that takes place becomes more generative, and the problem solving strategies need to be more responsive. This is where they see iterative and agile design principles well suited (Figure I). This is also a close description of the conditions where heutagogical approaches can be most productive for 21 st Century learners (Blaschke \& Hase, 2016).

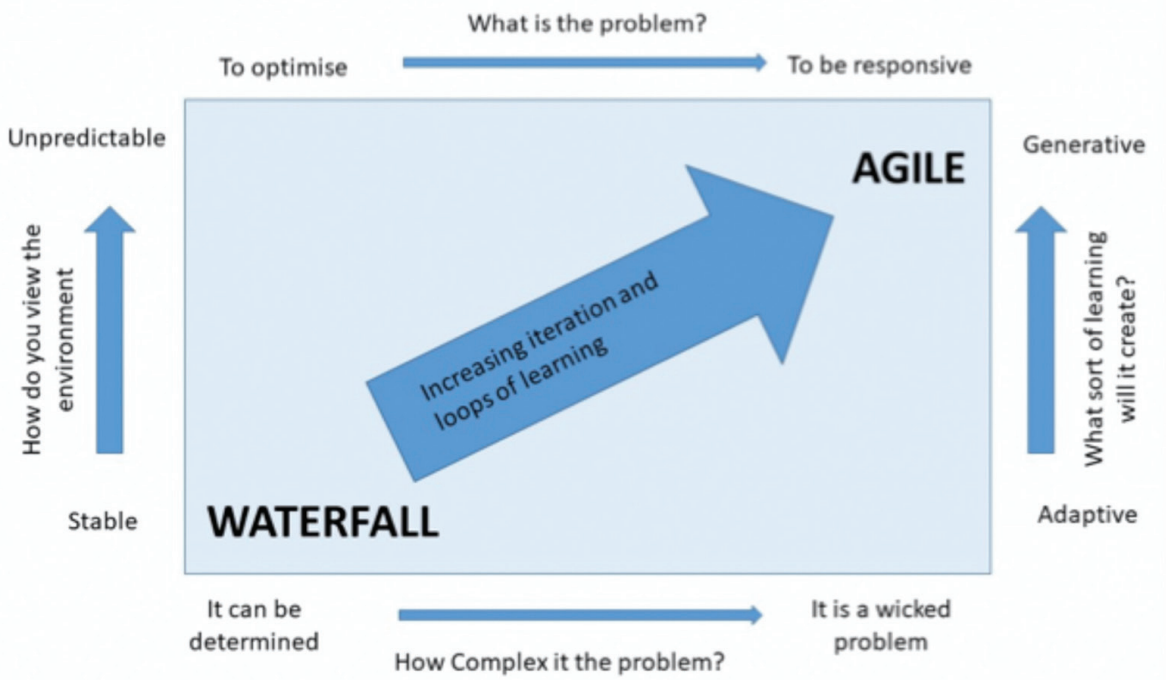

Figure I. Relationship between type of problem and agility. Based on Nerur \& Balijepally (2007). 
While some research has been undertaken which informs learning design that embraces heutagogy, it has approached it from the learning designer's or institutional perspective (Mann, Ker, Eden-Mann, \& O 'Brien, 20 I7; Narayan et al., 20 I8). It is not clear whether previous research has explicitly explored the synergy between heutagogy and agile design principles.

There does not appear to be any literature available that describes the design process that a learner will undertake within the context of self-determined learning from the learners perspective. As heutagogy is founded on the learner having agency to determine what, when and how they learn, this is a significant gap in the literature.

\section{SAMPLE OF NARRATIVE}

As a learner in a Doctorate of Professional Practice I have two processes to undertake in the first year.The first is a review of learning that allows me to articulate my position professionally and paradigmatically. The second process is negotiating a learning agreement. The agreement requires a detailed description of the learning and research I will undertake in the second and third years. As Illustrated in Fig. 2 the learning agreement must show how my practice will be transformed from my current framework of practice to an aspirational framework.

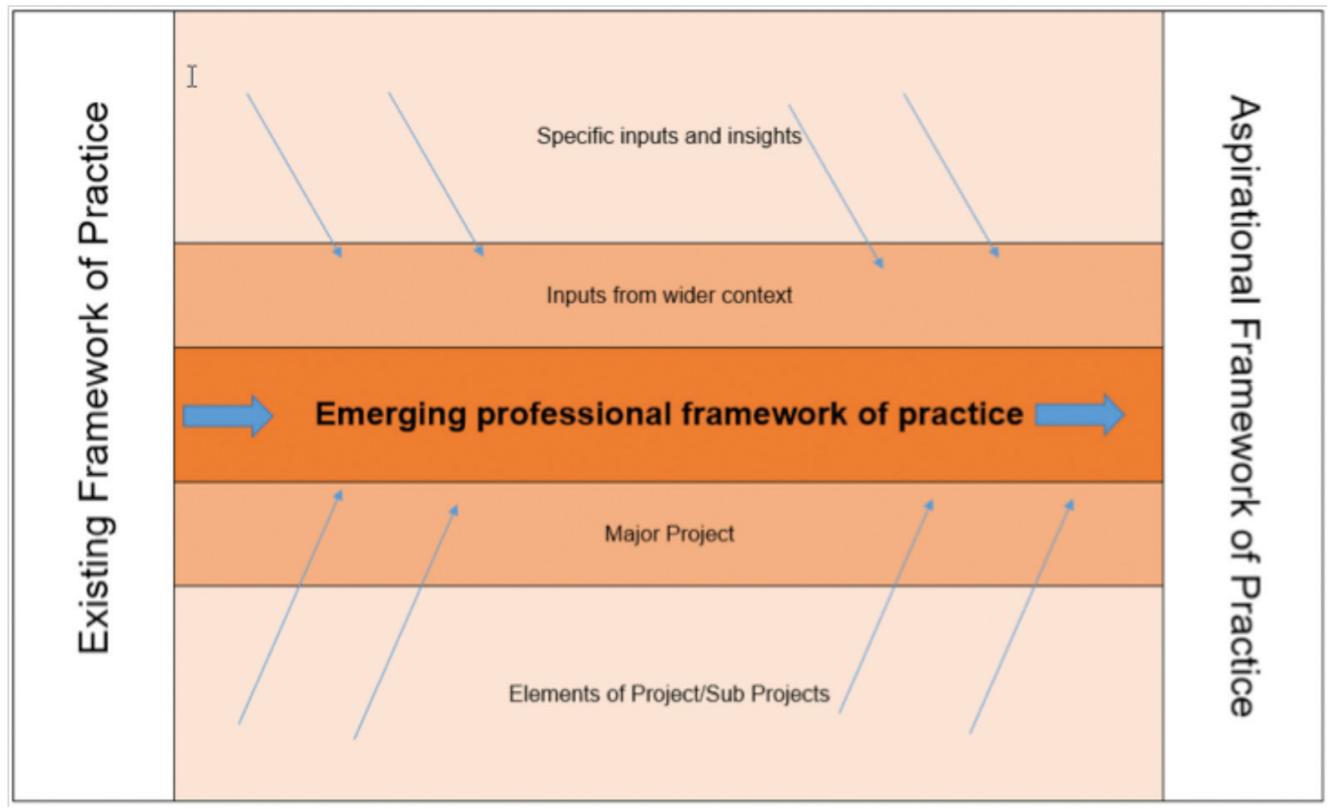

Figure 2. Doctor of Professional Practice learner's interpretation of processes.

The series of quotes below are sampled from the narrative of my learning agreement. They provide a quick fly-past account of critical stages in the design process starting from defining my current practice, a series of iterations and insights, and ending at a better defined aspirational framework of practice. While the context of my research is not directly relevant to this article, the extent and frequency with which it changes direction is significant.

"My initial aspiration to be a practice leader in Social Edupreneurship as a model for transformational education was driven by my pragmatic need to make a difference (O'Brien, 20 I 8)."

"I critically reflected upon the significance and implications of my initial approach. The most significant limitation of the proposed framework from my perspective was that identifying as a social edupreneur could become a boundary around my practice, rather than an extension of my practice." 
"As a result of this critical reflection I no longer saw the framework of Social Eduprenuership as an effective articulation of my aspirational framework of practice or professional identity. However I did still see the potential that the exercise of developing the framework of social eduprenuership could be an appropriate project through which to develop the capabilities and range of approaches that were at my disposal as a professional."

"Malcolm Gladwell describes the tension I was grappling with well:

"Our world requires that decisions be sourced and footnoted, and if we say how we feel, we must also be prepared to elaborate on why we feel that way... We need to respect the fact that it is possible to know without knowing why we know and accept that - sometimes - we're better off that way." (Gladwell, 2006, p. 52).

"... having worked across all of the stages in the [learning design ] process I do not identify more strongly with any specific stage or specialism. To varying extents, I have demonstrated capabilities across them all. Therefore the catchall term Learning Designer is the best descriptor of my current framework of practice."

"The reflection on, and clarification of my current framework of practice prompted a comparison to the role of designer/developer in a software design context. This allowed me to see the similarities between my current practice and that of a Full-Stack software developer."

"The emergent idea based on my own experience, is that the concept of Full-stack seemed equally applicable to learning design as it is to software design. That being the case, it is also prudent to consider the extent to which the agile methods of working which full stack developers generally adopt are relevant."

"This definition [of complex adaptive systems] is directly applicable to the three complex challenges which are driving the development of this aspirational framework of practice; tension between compliance and the need for individualised future-focussed learning, an exponential rate of change in education, and the need for learning experiences to be fit-for-future-purpose, including supporting sustainable development."

"It does not appear that Complex Adaptive Systems have been used as a concept to inform learning design."

"Reflecting upon the model of a full stack software developer I realised that user experience design (Ux Design) sits at the top of the stack. It is the starting point for design. Priority is given to the question what experience should the user have to meet their needs?"

"With this insight, I propose flipping the learning design stack to show the priority learner experience should take within this framework."

"If we do not have a clear understanding of how to lead $L x$ design practice and culture, the learners' experience is unlikely to be recognised at the strategic level it merits."

"It is clear that we need the learner's experience to be the focal point of learning design- the Lx Design Leader can be an agile agent for change in a complex system."

"... reinforces that the strongest and most central theme in the transformation of my practice is developing my capability to embrace the complexity of the environment and tasks that a future focussed learning designer must engage with."

"The current iteration of my aspirational framework of practice is: Practitioner Research: Learning Design for Complexity of Learning, and Global Regenerative Impact."

These samples from my narrative show how my research proposal took many pivots and turns before setting on an aspirational goal.This happened in a very organic fashion without a framework or structure to guide it. This required 


\begin{tabular}{|c|c|c|c|}
\hline Input/Insight & Analysis or Evaluation & Synthesis & Communication/Delivery \\
\hline $\begin{array}{l}\text { This could be an } \\
\text { experience, reflection, } \\
\text { observation, literature, } \\
\text { feedback, or professional } \\
\text { insight. }\end{array}$ & $\begin{array}{l}\text { This could be a } \\
\text { comparisons, a rating } \\
\text { against standards, a } \\
\text { measurement of impact, } \\
\text { monitoring of progress, a } \\
\text { prescribed process..... }\end{array}$ & $\begin{array}{l}\text { This could be a reflection } \\
\text { that creates more } \\
\text { understanding, the } \\
\text { drawing of a new model, } \\
\text { the setting of a new } \\
\text { course, or the adaptation } \\
\text { of a research question. }\end{array}$ & $\begin{array}{l}\text { This is the doing based } \\
\text { on the synthesis of } \\
\text { the new insight or the } \\
\text { communication of the } \\
\text { synthesis to provide } \\
\text { another insight and loop } \\
\text { of learning. }\end{array}$ \\
\hline $\begin{array}{l}\text { Based on the reflections } \\
\text { in my Review of Learning, } \\
\text { I realised the extent to } \\
\text { which I am motivated to } \\
\text { make a difference and } \\
\text { that I prefer to adopt a } \\
\text { pragmatic lens on doing } \\
\text { so. }\end{array}$ & $\begin{array}{l}\text { I compared a traditional } \\
\text { approach to education } \\
\text { and learning design to } \\
\text { the impact being made } \\
\text { by social enterprise, } \\
\text { the rate of change in } \\
\text { entrepreneurship and } \\
\text { the breadth of context in } \\
\text { sustainability. }\end{array}$ & $\begin{array}{l}\text { I put together a model } \\
\text { for education that drew } \\
\text { on all of the elements in } \\
\text { the comparison- Social } \\
\text { Edupreneurship. }\end{array}$ & $\begin{array}{l}\text { I communicated this } \\
\text { model to colleagues, } \\
\text { presented it at a } \\
\text { symposium and published } \\
\text { it in a journal to test-fly } \\
\text { the concepts and get } \\
\text { feedback. }\end{array}$ \\
\hline $\begin{array}{l}\text { Refection on the } \\
\text { concept of Social } \\
\text { Edupreneurship identified } \\
\text { it as a potentially limiting } \\
\text { structure rather than an } \\
\text { enabling model- I was } \\
\text { creating my own pigeon } \\
\text { hole. }\end{array}$ & $\begin{array}{l}\text { I compared the role } \\
\text { I had envisioned as a } \\
\text { social edupreneur and } \\
\text { my current role and saw } \\
\text { that the key challenges } \\
\text { we face in education } \\
\text { remained constant } \\
\text { no matter what the } \\
\text { approach. }\end{array}$ & $\begin{array}{l}\text { I tried to synthesise the } \\
\text { broader perspective } \\
\text { and fit designing Social } \\
\text { Edupreneurship as step } \\
\text { within my professional } \\
\text { development rather than } \\
\text { the end goal. }\end{array}$ & $\begin{array}{l}\text { I was able to articulate } \\
\text { my own current } \\
\text { framework of practice } \\
\text { more clearly. }\end{array}$ \\
\hline $\begin{array}{l}\text { Having a clearer picture } \\
\text { of my current frame } \\
\text { work made it easier to } \\
\text { relationships with other } \\
\text { frameworks }\end{array}$ & $\begin{array}{l}\text { I compared my } \\
\text { framework to the } \\
\text { professional framework } \\
\text { of designers in the IT } \\
\text { sector. }\end{array}$ & $\begin{array}{l}\text { I synthesised concepts } \\
\text { around the primacy of } \\
\text { user experience and the } \\
\text { diversity of capabilities } \\
\text { required to be agile. }\end{array}$ & $\begin{array}{l}\text { I articulated a several } \\
\text { iterations of a possible } \\
\text { future framework of } \\
\text { practice. For example, } \\
\text { Full-Stack Learner } \\
\text { Experience designer. }\end{array}$ \\
\hline $\begin{array}{l}\text { With so many different } \\
\text { elements entering } \\
\text { each iteration of my } \\
\text { aspirational framework of } \\
\text { practice, I realised (with } \\
\text { some guidance from my } \\
\text { supervisors) that keep } \\
\text { the size of the project } \\
\text { within the scope of the } \\
\text { qualification was going to } \\
\text { be challenging. Some the } \\
\text { learners on the course I } \\
\text { teach had the same issue. }\end{array}$ & $\begin{array}{l}\text { I stepped away from my } \\
\text { work for } 2 \text { weeks and } \\
\text { did some reading on } \\
\text { complexity. I compared } \\
\text { the process of learning } \\
\text { design to the criteria } \\
\text { of a Complex Adaptive } \\
\text { System (CAS). Learning } \\
\text { design does appear to be } \\
\text { complex and adaptive. } \\
\text { All of the elements I } \\
\text { had introduced were } \\
\text { interrelated. }\end{array}$ & $\begin{array}{l}\text { I reviewed my approach } \\
\text { to learning design and } \\
\text { rather than a linear set } \\
\text { of tasks and independent } \\
\text { inputs, I introduced the } \\
\text { language and concepts of } \\
\text { complexity theory. }\end{array}$ & $\begin{array}{l}\text { Learning Design for } \\
\text { Complexity of Learning, } \\
\text { and Global Regenerative } \\
\text { Impact. }\end{array}$ \\
\hline
\end{tabular}

Figure 3. Reflection on use of agile design. 
that I had the confidence (or arrogance) to break away from a more traditional hypothesis focussed approach to designing my research. It also required my supervisors to have a level of confidence in my ability to either be successful thought this approach, or that I had the resilience to recover if it led to a dead end.

I am employed in two different transdisciplinary units. One is a learning and teaching development team which work with all schools and colleges across a tertiary education institution (Otago Polytechnic). The second is a work-based/ professional practice learning faculty (Capable NZ) that delivers qualifications in several practice disciplines through a facilitation model. These roles has made me very comfortable crossing from one discipline to another, and given me access to influences across a wide spectrum of knowledge and expertise. These are luxuries that few learners are afforded, but were key to me being able to adopt an agile approach to designing my own learning within a programme based in heutagogical principles. This prompted me to reflect upon the process I had undertaken and identify a framework that could be used by other learners and supervisors to move towards a more agile process.

\section{REFLECTION ON PROCESS}

The framework I propose is based on the common steps of an agile design process as identified in the review of literature: Input/insight, analysis or evaluation, synthesis and communication/delivery. To reflect upon the process I have unpacked the sample of the narrative provided to allow the process to be more visible. I have used the learning design strategy of creating a simple story board (Van Der Lelie, 2006). The table in Figure 3 is the storyboard for the sample of the narrative provided. Each column being a stage in the process and each row describing the process iteration by iteration. It should be noted that this is not a complete account of the learning, but merely a representative sample.

The first step is the input or insight which triggers a new iteration. This could be an experience, reflection, observation, literature, feedback, or professional insight. In this instance I refer to professional insights as insights gained from being part of a professional context such as mentoring conversations, group/network discussions, industry literature, or industry linked social media content.

The second step, analysis or evaluation, could be comparisons, a rating against standards, a measurement of impact, monitoring of progress, undertaking a prescribed process, an audit, or a self-critique.

Synthesis could be a reflection that creates more understanding, the drawing of a new model, the setting of a new course, or the adaptation of a research question. It shows the new ideas working alongside the old.

The final step in each iteration is communication or delivery. Arguably communication can be considered a type of delivery. This is the doing based on the synthesis of the new insight or the communication of the synthesis. Most importantly this is the link from one iteration to the next.

The text in Figure 3 provides a link between the sample narrative and the agile process that I followed.

\section{CONCLUSIONS}

Based on the relationship between agile design and heutagogy I reflected upon my own practice and the many iterations in planning a research project. While not deliberately incorporated into the process, when examined in a storyboard four common elements of agile design were apparent. The storyboard retrospectively used in this article, may be of use in a more proactive manner to provide a guiding structure for professional practice learners and supervisors looking to engage with the benefits of a more agile design process. Figure 4 provides a basic tool which could be used for planning as it is or with adaptions to better suit the learning context. 


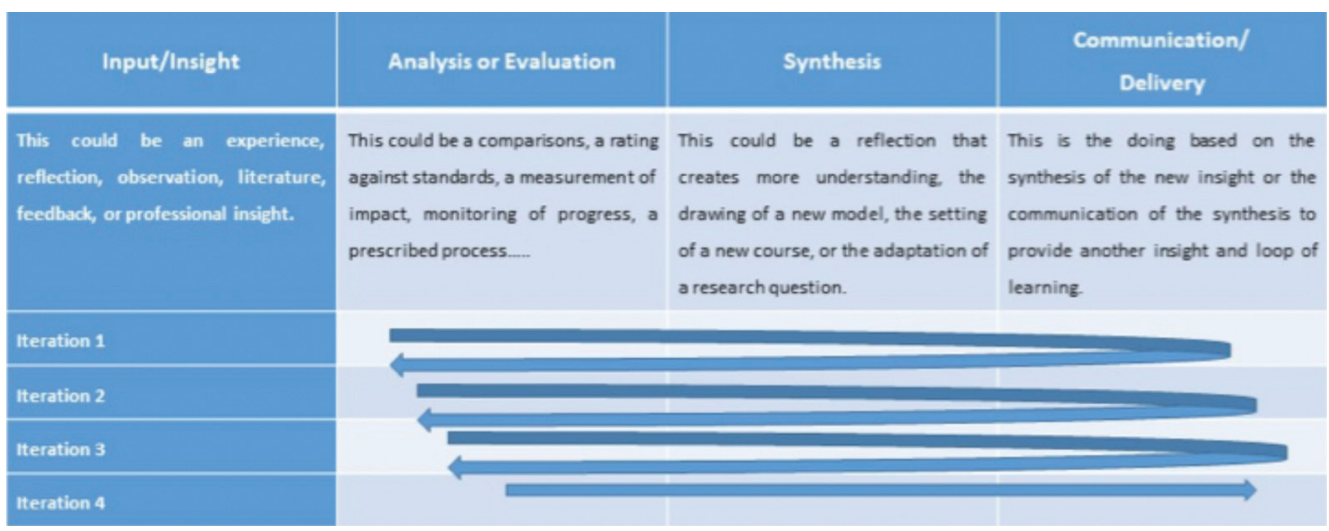

Figure 4. Storyboard tool for agile design of professional practice learning.

While this tool has only been tested in retrospect on my own learning, the common elements of agile design within it are well established and accepted. The tool has been developed through post graduate professional practice learning, but there may be merit in further research to explore its application to other sectors. This may be particularly relevant to the New Zealand secondary school sector as their curriculum moves towards a more project based pedagogy(Ministry of Education, 2019).

Ray O'Brien works across several areas at Otago Polytechnic, but at the core of all of them he is a learning designer. He has been part of the team designing and implementing the Bachelor of Leadership for Change and specialises in the integration of sustainable practice into programmes across many disciplines. 


\section{REFERENCES}

A Designer's Introduction to "Agile" Methodology. (2015). Retrieved 25 April 2019, from Web Design Envato Tuts+ website: https:// webdesign.tutsplus.com/articles/a-designers-introduction-to-agile-methodology--cms-23349

Agile Alliance. (200I). Principles behind the Agile Manifesto. Retrieved 25 April 2019, from https://agilemanifesto.org/principles.html

Agonács, N., \& Matos, J. F. (2019). Heutagogy and self-determined learning: A review of the published literature on the application and implementation of the theory. Open Learning: The Journal of Open, Distance and e-Learning, O(0), I-18. https://doi.org/I 0 . 1080/026805 | 3.2018.1562329

Allen, M., \& Sites, R. (2012). Leaving ADDIE for SAM: An Agile Model for Developing the Best Learning Experiences. American Society for Training and Development.

Ambler, S. (200I). Agile Design. Retrieved 25 April 2019, from http://agilemodeling.com/essays/agileDesign.htm

Arimoto, M. M., Barbosa, E. F., \& Barroca, L. (20I5). An agile learning design method for open educational resources. 2015 IEEE Frontiers in Education Conference (FIE), I-9. https://doi.org/ I 0. I I09/FIE.20 I 5.7344334

Bagnall, J., \& Koberg, D. (198I). The All New Universal Traveler: A Soft Systems Guide to Creativity,Problem-Solving and the Process of Reaching Goals. Los Altos, CA:W. Kaufmann.

Balaji, S., \& Murugaiyan, M. (20I2). Waterfall model vs v-model vs agile: A comparative study on SDLC. International Journal of Information Technology and Business Management, 2(1), 26.

Blaschke, L. M. (2012). Heutagogy and lifelong learning: A review of heutagogical practice and self-determined learning. The International Review of Research in Open and Distributed Learning, I3(I), 56. https://doi.org/I0.19173/irrodl.vI 3il. 1076

Blaschke, L. M., \& Hase, S. (2016). Heutagogy: A Holistic Framework for Creating Twenty-First-Century Self-determined Learners. In B. Gros, Kinshuk, \& M. Maina (Eds.), The Future of Ubiquitous Learning (pp. 25-40). https://doi.org/ I 0. I007/978-3-662-477243_2

Cochrane, T., \& Narayan, V. (2013). Redesigning professional development: Reconceptualising teaching using social learning technologies. Journal of Research in Learning Technology, 2 I. Retrieved from https://search.proquest.com/docview/2121431797/ fulltextPDF/82C | 4942D58A4A8CPQ/l ?accountid=39660

Cockburn, A. (2006). Agile Software Development:The Cooperative Game. Pearson Education.

Conboy, K. (2009). Agility from First Principles: Reconstructing the Concept of Agility in Information Systems Development. Information Systems Research, 20(3), 329-354. https://doi.org/ I 0.1287/isre. 1090.0236

Cross, N. (200 I). Designerly Ways of Knowing: Design Discipline versus Design Science. Design Issues, 17(3), 49-55. Retrieved from http://www.jstor.org/stable/I5 | | 80 |

Dam, R., \& Siang,T. (2019). 5 Stages in the Design Thinking Process. Retrieved 25 April 20 I 9, from The Interaction Design Foundation website: https://www.interaction-design.org/literature/article/5-stages-in-the-design-thinking-process

Dingsøyr, T., Nerur, S., Balijepally, V., \& Moe, N. B. (2012). A decade of agile methodologies: Towards explaining agile software development. Journal of Systems and Software, 85(6), I 2 I 3-1221. https://doi.org/ / 0. I 01 6/j.jss.20 I 2.02.033

Duberly, H. (2004). How do you do design? San Francisco, CA: Dubberly Design Offi ce.

Erickson, J., Lyytinen, K., \& Siau, K. (2005). Agile Modeling, Agile Software Development, and Extreme Programming: The State of Research. Journal of Database Management, I6(4), 88-100. https://doi.org/ | 0.40 I 8/jdm.2005 I 00105

Gladwell, M. (2006). Blink:The power of thinking without thinking. New York, USA: Little, Brown and Co.

Hase, D. S. (2016). Self-determined Learning (heutagogy): Where Have We Come Since 2000? Special Edition of Southern Institute of Technology Journal of Applied Research., 21.

Henderson-Sellers, B., \& Serour, M. K. (2005). Creating a dual-agility method:The alue of method engineering. Journal of Database Management, 16, I-4. https://doi.org//0.4018/jdm.2005 I00 I0 I

Highsmith, J., \& Cockburn, A. (200 I). Agile software deveoplement:The business of innovation. Computer, 34(9), I20-127. Retrieved from http://www.adaptivesd.com-www.adaptivesd.com/articles/IEEEArticle I Final.pdf

Holmes, G., \& Abington-Cooper, M. (2000). Pedagogy vs. Andragogy: A False Dichotomy? The Journal of Technology Studies, 26(2). https://doi.org/| 0.2106|/jots.v26i2.a.8

Kenyon, C., \& Hase, S. (200 I). Moving from andragogy to heutagogy in vocational education. Proceedings of the 4th Annual Australian Vocational Education and Training Research Association (AVETRA) Conference, 8.

Kumar,V. (2003). Innovation planning: Modes, tools, uses. Humans Interaction Technology Strategy Conference, I6-17. Chicago: Chicago Historical Society.

Mann, S., Ker, G., Eden-Mann, P., \& O 'Brien, R. (2017). Qualified to surf chaos: A self-determined degree. Scope: Contemporary Research Topics., Flexible Learning(4), 24-38. Retrieved from http://www.thescopes.org/assets/Uploads/Mann-BLfC.pdf 
Mann, S., Ker, G., Eden-Mann, P., \& O'Brien, R. (2017). Designing for Heutagogy:An Independent Learning Pathway Approach. Capable - Scope: (Flexible Learning), 2, 59-70.

Merriam, S. B. (200I). Andragogy and Self-Directed Learning: Pillars of Adult Learning Theory. New Directions for Adult and Continuing Education, 2001 (89), 3-14.

Ministry of Education. (2019). NCEA Review. Retrieved 5 August 2019, from https://conversation.education.govt.nz/conversations/ ncea-review/

Murthi, N. (2017). Top 5 Industries That Are Adopting Agile Other Than Software. Retrieved 25 April 2019, from Agile Seeds website: http://agileseeds.com/agile-in-other-industries/

Narayan, V., Herrington, J., \& Cochrane, T. (20।8). Design principles for heutagogical learning: Implementing student-determined learning with mobile and social media tools. Australasian Journal of Educational Technology, 35(3), 86-101. https://doi. org/l0.14742/ajet.394I

Nerur, S., \& Balijepally, V. (2007). Theoretical reflections on agile development methodologies. Communications of the ACM, 50(3), 79-83. https://doi.org/10.1 |45//226736.1226739

O'Brien, R. (2018). Social Edupreneurship - An Emerging Professional Framework for Educators. Scope-Contemporary Research Topics, Flexible Learning(3), 38-40. Retrieved from https://www.thescopes.org/assets/Uploads/la l c5ab9c7/38-Scope-FlexibleLearning-3-o-brien.pdf

Palmquist, M. S., Lapham, M. A., Miller, S., Chick, T., \& Ozkaya, I. (2013). Parallel worlds: Agile and waterfall differences and similarities (Technical Notes No. CMU/SEI-20 I3-TN-02 I; p. I0I). Carnegie Mellon University.

Rengifo, E. (2018, March 13). Iterations in the Design Process. Retrieved 12 May 20 I9, from Prototypr website: https://blog.prototypr. io/iterations-in-the-design-process-4 I bd8d0 I f244

Ries, E. (2017). The Startup Way: How Entrepreneurial Management Transforms Culture and Drives Growth. Penguin UK.

Van Der Lelie, C. (2006). The value of storyboards in the product design process. Personal and Ubiquitous Computing, 10(2-3), 159-162. https://doi.org/10.1007/s00779-005-0026-7 